\title{
Explaining County Government Fiscal Transparency in an Age of e-Government
}

State and Local Government Review 2014, Vol. 46(3) 173-183 (C) The Author(s) 2014 Reprints and permission: sagepub.com/journalsPermissions.nav DOI: 10.1 I77/0160323X14556819 slgr.sagepub.com

\author{
E. Lee Bernick', Jonathan M. Birds', \\ Katheryn Brekken ${ }^{2}$, Al G. Gourrier', \\ and Leander D. Kellogg'
}

\begin{abstract}
This research seeks to explain the fiscal transparency practices of individual U.S. counties by examining the extent of information shared with constituents via county government Web sites. This study evaluates a random sample of 400 U.S. counties, where 19 percent of those represented have populations of 100,000 or more residents, matching the same ratio of counties with populations of 100,000 or more residents nationally. We create a four-level categorical dependent variable measuring fiscal transparency and use a generalized ordered logit analysis with eight independent variables to explain the extent of fiscal transparency among the sample.
\end{abstract}

\section{Keywords}

e-Government, budgets, county government, transparency

American county governments-once considered the "forgotten governments" of local government research (Menzel et al. 1992, 176), and even labeled negatively as "the headless wonder," "the jungle of the American political scene," and "a backward institution"- - have become the focus of a growing body of research (Benton 2005, 462; Benton et al. 2007, 968). In 1992, twelve scholars initially proposed eight areas of study to better understand the American county: structure, reform, and performance; leadership and professional management; size, equity, and responsiveness; environment and performance; counties as laboratories of democracy; counties in the American federalism system; fiscal roles and relationships; and counties in a global society (Menzel et al. 1992). Fifteen years later, half of those scholars - along with others - updated this agenda to include information technology (Benton et al. 2007). Building upon the information technology or e-government category, Benton et al. $(2007,997)$, posed the question, "To what extent are counties utilizing Web sites to disseminate information and to reduce the need for citizens to travel to the courthouse to pay taxes and fees and complete other business?" As the number of Americans online continues to increase along with their frequency of use

\footnotetext{
' University of Nevada, Las Vegas, NV, USA

${ }^{2}$ College of Southern Nevada, University of Nevada, Las Vegas, NV, USA

Corresponding Author:

E. Lee Bernick, University of Nevada, Las Vegas, $4505 \mathrm{~S}$. Maryland Parkway, Box 454030, Las Vegas, NV 89154, USA. Email: lee.bernick@unlv.edu
} 
(Mossberger, Tolbert, and McNeal 2008), the growing body of research on counties should also include how local governments are using this medium to facilitate civic engagement and interaction with constituents. This research seeks to begin addressing these gaps and explain fiscal transparency practices of individual U.S. counties by examining what fiscal information they share with constituents on their Web site.

\section{Literature Review}

The literature on e-government practices is still relatively inadequate as studies began in the late 1990s and early 2000s (Stowers 1999; Ho 2002; Carter and Belanger 2005; Wilkinson and Cappel 2005; Huang 2007). Furthermore, the literature on county e-government is even more bereft, as much of the existing research has focused at the national level (Kopits and Craig 1998; Heald 2003; Benito and Bastida 2009). One of the most comprehensive studies on county e-government found that of the 3,099 American counties, 1,744 (56.3 percent) had Web sites, and of those, only 720 Web sites contained county budget information (Huang 2007). Manoharan (2013a, 160, 172) conducted additional research, using survey information from 343 counties, and identified specific factors that led counties to adopt various egovernment strategies. Specifically, he found that institutional factors (such as technical capacity and organizational size) are the strongest predictor for county e-government adoption or the "delivery of services and information electronically." Additionally, Manoharan (2013a, 2013b) found that 23.5 percent of all U.S. counties had not adopted official Web sites. However, the study did not look at fiscal transparency specifically.

Other research has examined the evolution of local e-government. In spite of the public's rapid adoption of the Internet, Norris and Reddick (2013) found that there has been no corresponding shift in constituents' expectations of public service delivery online and therefore no rapid transformation in e-government practices. The development of e-government, in fact, has been one directional from government to citizens and not an interactive process. There are numerous opportunities to expand the use and benefits of the Internet in public service delivery, particularly in the exchange of fiscal information between government and taxpayers. Although general Web site development and use of the Web are accelerating dramatically, "budgetary information on many governmental websites has not shown a similar pattern of evolution" (Joaquin and Greitens 2011, 306).

In general, budget or fiscal transparency in the public sector is important and allows governments to be held accountable for decisions. Furthermore, Kopits and Craig $(1998,2)$ found that governments exhibiting high levels of fiscal transparency showed greater fiscal discipline and more robust economic performance.

Fiscal transparency has been defined in the literature in varying ways. Several of the key meanings are "openness toward the public at large about government structure and functions" (Kopits and Craig 1998, 1), "an effective role for civil society through the media and non-governmental organizations" (Benito and Bastida 2009, 404), and "institutional transparency, accounting transparency, and transparency of indicators" (Heald 2003, 732). Dye, Hudspeth, and Merriman (2011) built upon the body of literature and identified five aspects of fiscal transparency: budget process or cycle; public disclosure and distribution of budget information; budget document contents; budget integrity, control, and accountability; and budget forecasting and projections. Of these five aspects of fiscal transparency, three are of particular interest to this research:

- Public disclosure and distribution of budget information is further defined, "Once the budget is crafted, is the information disclosed to the public and the press on the Internet or in some other easily accessible form?"

- Budget document contents is further defined as the items that should be included in a budget document 
including, "detailed revenue and expenditure categories, a comprehensive scope, accounting for assets and liabilities, targets, projections, performance measures, earmarking, and a measure of structural balance."

- Budget integrity, control, and accountability are further defined as "disclosure of techniques and practices, and audits" (Dye, Hudspeth, and Merriman 2011, 4).

Scholars have attempted very few empirical studies to measure fiscal transparency. The few that have done so focused on national and state indicators, ignoring local governments. Most recently, Harder and Jordan (2013) conducted a content analysis of county Web sites throughout the state of Arkansas to examine transparency. The authors created a transparency scorecard of thirty-four indicators, the most basic of which was the display of budget information on the county's Web site. A few of their key conclusions were as follows:

- Less than half of the counties had Web sites.

- Of the thirty-four points possible, the average score was 9.17.

- Counties that had smaller populations, were older, and had more poverty did not have Web sites.

- Regression analysis found that population growth and high school graduations positively affected transparency scores.

Based on the previous findings, there is much that we have yet to learn about county e-governance and fiscal transparency.

\section{Method}

This study looks at the level of county fiscal transparency at one point in time in 2014. There are more than 3,000 county governments in the United States. For the purposes of this study, we select a random sample of 400 counties to analyze. In constructing the sample, we create a stratified sample with one stratum for counties with more than 100,000 residents, which we refer to as large counties, and a second stratum for all those counties with fewer than 100,000 residents, which we will call small counties, for the sake of differentiation. The first stratum contains 19 percent of the sample (76 counties), which represents the percentage of large counties among the United States' total 3,138 counties (as defined by the American Community Survey [ACS] and National Association of Counties' [NACO] Web site). Besides two states that do not officially have county governments, Maine is the only state that does not have at least one county, or its equivalent, in the sample. Having drawn the sample, we use NACO's "Find a County," Google Search, and state governments' Web sites to determine how many counties in the sample have Web sites. We then examine each county with a Web site and conduct a content analysis of the site to evaluate the county on a number of issues. Fiscal transparency is just one of several topics we explore in the context of a larger research project. Examination of Web sites allows us to create the dependent variable: Fiscal Transparency.

The dependent variable, Fiscal Transparency, is an ordinal measure with four levels of increased fiscal information based on data from county Web sites. The lowest of the four categories is indicative of no fiscal information on the Web site while counties in the fourth category have three fiscal-related items. Placement of a county in one of the four categories is determined from analysis of three criteria. First, does a county have budget information on its Web site (coded as a $0=$ no information and $1=$ budget information available)? Second, if the county has a budget on its Web site, what type of budget is presented? Thus, every county with a budget online is further examined to determine the nature of the budget information. The test for this element is whether the information goes beyond a simple line-item budget of revenues and expenditures to a more comprehensive budget presentation with elements suggested by the Government Finance Officers Association's National Advisory Council on State and Local Budgeting (NACSLB 1998). Budgets are coded as 0 if they are line item and 1 if they are more sophisticated. More detailed 
analysis of the comprehensive budget elements suggested by the NACSLB may be an area of exploration in the future but are not conducted for the purposes of this study. The third element in creating the dependent variable is to determine if a county provides information concerning their Comprehensive Annual Financial Report (CAFR; $0=n o$, CAFR present $=1$ ). Thus, the dependent variable's four categories are as follows:

$0=$ no fiscal information;

$1=$ a simple budget presentation or a CAFR;

$2=$ a simple line-item budget and CAFR or the existence of a more sophisticated county budget;

$3=$ a CAFR and a more sophisticated budget are present.

The dependent variable is an ordinal variable; as a result, an ordered logit analysis is an appropriate statistical model (Long and Freese 2006). In an ordered logit model, an important assumption is that the slope coefficients for the explanatory variables do not vary across the alternatives - commonly referred to as the parallel lines assumption (Williams 2006). If this assumption is violated, then substantive interpretation of the results may be incorrect. However, Williams (2006) has created a partial proportional odds model that allows us to relax the parallel lines assumption for those explanatory variables that do not meet the parallel line assumption while constraining the other variables meeting the assumption. Thus, the partial proportional odds model permits a more accurate substantive interpretation of the impact of the eight independent variables used to explain county governments' Fiscal Transparency.

\section{Independent Variables}

The eight independent variables employed in the analysis include four that measure aspects of the structure of county government: the size of the elected county board, whether the county has an appointed county manager (or its equivalent), the number of full-time equivalent employees (FTE) classified as having an administrative function, and a nominal level variable indicating whether a county submitted an audit report to the federal government under Office of Management and Budget-Circular 133 requirements. Counties are communities often composed of a complex set of individuals. Thirteen variables were selected to capture the economic, political, and social environment of counties. Twelve of the thirteen come from information found from the U.S. Census Bureau's Web site and its ACS. The last of the thirteen variables used in the factor analysis is the percentage of votes President Obama received in 2012 within a county (this information was obtained from the Politico Web site). However, rather than treat the thirteen variables as separate predictors, it was decided to conduct a factor analysis to determine if there was commonality within the variables. The factor analysis permits a more parsimonious analysis of the environmental characteristics of counties. The factor analysis resulted in four factors labeled Economic Stress, Older/Vacation, Minority/Democratic, and Heterogeneity and serve as the four other independent variables used in the analysis.

The thirteen variables and their loadings on the four factors are presented in Supplemental Table 1. However, a brief explanation of each of the four is presented to aid in understanding the factors. Economic Stress is composed of six variables, including the level of poverty and the extent to which food stamps are used in a county. Two variables, Per Capita Income and Post-secondary Education have negative loadings on this factor. The second factor is named Older/Vacation since two of the three variables on this factor measure age including the percentage of citizens over sixty-five. The final variables loading on this factor measure the extent to which a county is a vacation destination as indicated by the extent to which there is seasonal housing. Minority/Democratic has five variables; however, the key to understanding this factor is the percentage of votes in the county for Obama in 2012. While population and education also load on this factor, analysis 
Table I. Independent Variables and Hypotheses.

\begin{tabular}{|c|c|c|c|}
\hline Variable & Expected Relationship & Rationale & Definition \\
\hline $\begin{array}{l}\text { Size of county } \\
\text { board }\end{array}$ & $\begin{array}{l}\mathrm{HI}: \text { the larger the elected } \\
\text { board the greater fiscal } \\
\text { transparency of the county. } \\
(+ \text { coefficient })\end{array}$ & $\begin{array}{l}\text { The larger the county board, } \\
\text { the more demand by } \\
\text { county officials for } \\
\text { information to satisfy } \\
\text { citizens' demands (Huang } \\
2007 \text { ) }\end{array}$ & $\begin{array}{l}\text { The variable counts the } \\
\text { number of elected board } \\
\text { members. There are a } \\
\text { number of different names } \\
\text { given to the elected board } \\
\text { members from across the } \\
\text { country, but we treat all of } \\
\text { them the same }\end{array}$ \\
\hline FTE & $\begin{array}{l}\mathrm{H} 2 \text { : the greater the FTE, the } \\
\text { greater the fiscal } \\
\text { transparency of the county. } \\
(+ \text { coefficient })\end{array}$ & $\begin{array}{l}\text { Counties with more } \\
\text { administrative capacity will } \\
\text { be able to provide more } \\
\text { information on their Web } \\
\text { sites and conduct more } \\
\text { sophisticated analysis } \\
\text { (Wilkinson and Cappel } \\
\text { 2005) }\end{array}$ & $\begin{array}{l}\text { This is the number of FTEs } \\
\text { working in an } \\
\text { administrative capacity as } \\
\text { reported in the Census of } \\
\text { Governments }\end{array}$ \\
\hline Audit & $\begin{array}{l}\text { H3: counties required to } \\
\text { submit an audit to the } \\
\text { federal government will be } \\
\text { more transparent. } \\
\text { (+ coefficient) }\end{array}$ & $\begin{array}{l}\text { Counties receiving federal } \\
\text { funds are more active and, } \\
\text { with the audit requirement, } \\
\text { already sharing information } \\
\text { with outside entities. } \\
\text { Regulation requiring local } \\
\text { government reporting } \\
\text { makes a difference in local } \\
\text { government practices } \\
\text { (Giles, Gabris, and Krane } \\
\text { I980; Ingram and DeJong } \\
\text { I987) }\end{array}$ & $\begin{array}{l}\text { The information for this } \\
\text { variable is gleaned from the } \\
\text { U.S. Census Bureau Web } \\
\text { site: Federal Audit } \\
\text { Clearinghouse. Data are for } \\
\text { the FY } 2012 \text { (the latest } \\
\text { available at the time of the } \\
\text { study). County was coded } \\
\text { as a "I" if it submitted an } \\
\text { audit to the federal } \\
\text { government and a " } 0 \text { " if not }\end{array}$ \\
\hline $\begin{array}{l}\text { Appointed } \\
\text { county } \\
\text { manager }\end{array}$ & $\begin{array}{l}\text { H4: counties with appointed } \\
\text { county managers will have } \\
\text { greater fiscal transparency. } \\
\text { (+ coefficient) }\end{array}$ & $\begin{array}{l}\text { Government structure makes } \\
\text { a difference (Benton 2003). } \\
\text { Local governments with } \\
\text { appointed managers act } \\
\text { differently than local } \\
\text { governments without } \\
\text { managers. Governments } \\
\text { with appointed managers } \\
\text { have a greater orientation } \\
\text { and capacity for reform } \\
\text { (Giles, Gabris, and Krane } \\
\text { I980) }\end{array}$ & $\begin{array}{l}\text { Data for this variable were } \\
\text { collected from county Web } \\
\text { sites, the National } \\
\text { Association of Counties' } \\
\text { Web site, and phone calls } \\
\text { to individual counties. A } \\
\text { county was coded as "I" if it } \\
\text { had an appointed county } \\
\text { manager and "0" if some } \\
\text { other structure existed }\end{array}$ \\
\hline $\begin{array}{c}\text { Economic } \\
\text { stress }\end{array}$ & $\begin{array}{l}\text { H5: counties with greater } \\
\text { economic stress will have } \\
\text { less fiscal transparency. } \\
\text { (- coefficient) }\end{array}$ & $\begin{array}{l}\text { Counties that have higher } \\
\text { levels of their population in } \\
\text { economic stress will not } \\
\text { have constituencies } \\
\text { demanding more } \\
\text { government transparency. } \\
\text { Conversely, counties with } \\
\text { low scores on this factor } \\
\text { are better off and will have } \\
\text { populations demanding } \\
\text { greater transparency (Ho } \\
\text { 2002; Wilkinson and } \\
\text { Cappel 2005; Huang 2007; } \\
\text { Harder and Jordan 2013) }\end{array}$ & $\begin{array}{l}\text { High scores indicate more } \\
\text { stress. Data from five-year } \\
\text { estimates of the American } \\
\text { Community Survey. Scores } \\
\text { are derived from the factor } \\
\text { analysis with a mean of "0" } \\
\text { and a standard deviation of } \\
\text { "I" }\end{array}$ \\
\hline
\end{tabular}


Table I. (continued)

\begin{tabular}{|c|c|c|c|}
\hline Variable & Expected Relationship & Rationale & Definition \\
\hline $\begin{array}{l}\text { Older/ } \\
\text { vacation }\end{array}$ & $\begin{array}{l}\text { H6: counties with an older } \\
\text { population will have less } \\
\text { fiscal transparency. } \\
\text { (- coefficient) }\end{array}$ & $\begin{array}{l}\text { Counties with older } \\
\text { populations and } \\
\text { homeowners who do not } \\
\text { reside in the county will } \\
\text { have less demand for } \\
\text { information to be } \\
\text { presented on a Web site } \\
\text { (Ho 2002; Harder and } \\
\text { Jordan 2013) }\end{array}$ & $\begin{array}{l}\text { High scores indicate older } \\
\text { vacation rental } \\
\text { communities. Data from } \\
\text { five-year estimates of the } \\
\text { ACS. Scores are derived } \\
\text { from the factor analysis } \\
\text { with a mean of "O" and a } \\
\text { standard deviation of "I" }\end{array}$ \\
\hline $\begin{array}{l}\text { Minority/ } \\
\text { Democratic }\end{array}$ & $\begin{array}{l}\text { H7: the more Democratic and } \\
\text { the more minority } \\
\text { residents, the greater the } \\
\text { fiscal transparency of the } \\
\text { county. ( }+ \text { coefficient) }\end{array}$ & $\begin{array}{l}\text { Democratic counties are } \\
\text { more liberal. The } \\
\text { assumption is that liberal } \\
\text { counties will want greater } \\
\text { transparency (Ho 2002; } \\
\text { Huang 2007) }\end{array}$ & $\begin{array}{l}\text { High scores indicate more } \\
\text { Democratic and more } \\
\text { minority counties. Data for } \\
\text { Democratic vote is the } \\
\text { percentage of county voting } \\
\text { for Obama in } 2012 \text {. Data } \\
\text { for other variables on this } \\
\text { factor come from the five- } \\
\text { year estimates for the ACS. } \\
\text { Scores are derived from the } \\
\text { factor analysis with a mean } \\
\text { of "0" and a standard } \\
\text { deviation of "I" }\end{array}$ \\
\hline Heterogeneity & $\begin{array}{l}\text { H8: the more heterogeneous } \\
\text { the county, the greater the } \\
\text { fiscal transparency. } \\
\text { ( }+ \text { coefficient })\end{array}$ & $\begin{array}{l}\text { County governments will use } \\
\text { websites as an effective } \\
\text { means to communicate } \\
\text { with diverse populations } \\
\text { and "reduce intermediate } \\
\text { barriers" with regard to } \\
\text { informing the community } \\
\text { (Ho 2002, p. 44I) }\end{array}$ & $\begin{array}{l}\text { High scores indicate larger } \\
\text { non-English-speaking popu- } \\
\text { lations. Negative scores } \\
\text { indicate a more homoge- } \\
\text { neous Anglo county. Data } \\
\text { for other variables on this } \\
\text { factor come from the five- } \\
\text { year estimates for the ACS. } \\
\text { Scores are derived from the } \\
\text { factor analysis with a mean } \\
\text { of " } 0 \text { " and a standard } \\
\text { deviation of "I" }\end{array}$ \\
\hline
\end{tabular}

Note: FTE = full-time equivalent employees; $\mathrm{ACS}=$ American Community Survey; FY $=$ fiscal year.

of the counties with the highest scores on this factor reveals that they are most likely to be very Democratic with a significant minority population. The final factor, Heterogeneity, contains three variables, including the Minority Population, the negative loading English Only Language, and the Percentage of Individuals without Health Insurance variables. Counties with high values on this factor are counties with higher percentages of non-English-speaking households, minority populations, and people in need of health insurance. We create factor scores for each county for each of the four factors, which then serve as values for our analysis. As a result of a varimax rotation in the factor analysis, the factor scores for the four variables are uncorrelated (see Supplemental Table 1).

Table 1 provides the list of variables, their definitions, sources, and the hypothesized relationships with a brief rationale. A positive relationship is hypothesized on six of the eight variables with higher values expected to explain an increased probability of being in the most open group of counties. The Economic Stress variable and the Older/Vacation variable 
are hypothesized to have negative relationships; in other words, an increase in the values on these two variables will result in a higher probability of a county being in the least open category (a value of 0 ).

\section{Findings}

This research seeks to examine the level of fiscal transparency in county government and possible explanatory factors in the variation of transparency (as defined by the dependent variable Fiscal Transparency). As noted previously, the dependent variable has four possible outcomes (from no budget information to three elements of financial information). An analysis of our random sample finds that approximately 9 percent or 35 of the 400 counties in the sample have no Web site. This is lower than the percentage found by Manoharan (2013b) or Harder and Jordan (2013), indicating that more counties are increasingly interested in communicating online. Of the 35 counties without Web sites, 23 or 65 percent were from traditionally Southern states with small (less than $100,000)$ populations. We eliminated the 35 counties with no Web sites from further analysis, as the focus of this research is whether a county with a Web site had fiscal information present. If the remaining 365 counties wanted to demonstrate transparency, then fiscal information would be available on their Web site (if not on their home page). In fact, 45 percent of the counties have no fiscal information anywhere on their Web sites. The remaining 55 percent of the counties with financial information are somewhat evenly distributed across the three other categories. It is worth noting that of the 18 percent that have one fiscal element available on their Web sites, approximately one-fifth only have CAFRs. In other words, the number of counties that have actual fiscal information available online is closer to 50 percent and 15 percent have all three elements.

The analysis now turns to determining why some counties are more likely to provide fiscal information than others. The dependent variable measures not only the existence of fiscal information but also the extent of information.
In conducting an ordered logit analysis of an ordinal dependent variable, we rely on a series of regression equations. The first equation, gives "no fiscal information" a value of " 0 " and the remaining three categories a value of "1." In the second regression, "no fiscal information" and "one item" are scored as a "0" while the remaining two categories are given a value of "1." Finally, the first three categories are grouped and compared to the last category "three items." The first stage of the analysis is to determine whether the independent variables employed in the analysis act in a similar fashion in all three equations - this is known as the parallel lines assumption. If they meet the assumption, it is assumed that proportional odds exist for the variables. However, some variables may not meet the parallel lines test, and a violation of the assumption can lead to an incorrect analysis of the results (Williams 2006). There is a mechanism to correct for this violation and in the partial proportional odds model used in this research, variables not meeting the test are allowed to deviate from proportionality. Seven of the eight independent variables meet the parallel lines assumption, while one (Appointed Manager) fails the test. As a result, the Appointed Manager variable has two additional coefficients developed as shown under the $\gamma$ parameterization in Table 2.

In Table 2, we provide a simplified presentation of the general ordered logit analysis. There are, in fact, twenty-four coefficients in addition to the constants for the three logit analysis. But since seven of the eight are constrained to be the same across all three equations, we present only one set of coefficients for them and the three coefficients for the Appointed Manager variable.

In ordered logit analysis, the significance and direction of the coefficients are worth noting, but the coefficients cannot be interpreted as one would with linear regression coefficients. Thus, to aid in the interpretation of the results, Table 2 also presents the odds ratio for each variable. As can be seen in Table 2, seven of the eight variables were significant and in the expected direction. The four variables measuring the social, economic, and political nature of 
Table 2. Explaining County Fiscal Transparency (Generalized Ordered Logit Model).

\begin{tabular}{|c|c|c|c|}
\hline Independent Variable & Coefficients & Standard Errors & Odds Ratio \\
\hline Appointed manager & $.5117^{*}$ & .2573 & $1.668 \mid$ \\
\hline Size of county board & $.0538 * *$ & .0194 & 1.0553 \\
\hline FTE & .0051 & .0028 & 1.0052 \\
\hline Audit & $.6425^{* * *}$ & .2459 & 1.9012 \\
\hline Economic stress & $-.4434 * * * *$ & .1182 & 0.6418 \\
\hline Older/vacation & $-.2257^{*}$ & .1078 & 0.7979 \\
\hline Minority/Democratic & $.4779 * * *$ & .1417 & 1.6127 \\
\hline Heterogeneity & $.3287 * *$ & .1117 & 1.3892 \\
\hline \multicolumn{4}{|l|}{$\gamma_{-} \mathrm{I}$} \\
\hline Appointed manager & $.4704^{*}$ & .2140 & 1.6007 \\
\hline \multicolumn{4}{|l|}{$\gamma \_2$} \\
\hline Appointed manager & $.9348 *$ & .3946 & 2.5467 \\
\hline \multicolumn{4}{|l|}{$\alpha$} \\
\hline Constant I & -.8602 & .2492 & \\
\hline Constant 2 & -2.0262 & .2793 & \\
\hline Constant 3 & -3.9702 & .3995 & \\
\hline \multicolumn{4}{|l|}{ Summary statistics } \\
\hline \multicolumn{4}{|l|}{$N=36 I^{\mathrm{a}}$} \\
\hline \multicolumn{4}{|l|}{$\chi^{2}=104.36 * * *$} \\
\hline Pseudo $R^{2}=.1508$ & & & \\
\hline
\end{tabular}

Note: $\mathrm{FTE}=$ full-time equivalent employees.

${ }^{\text {aThe }} n$ of 361 is a reduction from the 365 budget Web sites as a result of missing data for four counties. $* p<.05, * * p<.01, * * * p<.001$.

the counties can be thought of as the antecedents to the county structural variables. Counties that could be characterized as more Democratic and with minority populations are 61 percent $(.6127 \times 100)$ more likely to have fiscal information posted on their Web sites. Similarly, the Heterogeneity variable provides support for the notion that the more diverse the county composition, the more likely there will be fiscal information posted; in fact, the more heterogeneous counties are 39 percent more likely to post fiscal information. The analysis also provided evidence that both the Economic Stress and the Older/Vacation variables are significant with negative coefficients. Transformation of the negative coefficients to odds ratios results in odds below 1.00 . Odds ratios at 0.6418 and 0.7979 can be interpreted as indicating no movement out of the lower category, meaning a county under economic stress is 64 percent more likely to remain in the "no fiscal information" category. In the succeeding two equations, these counties are in the category combining no fiscal information or reduced fiscal information. In a similar fashion, Older/ Vacation counties are 80 percent more likely to have no fiscal information than fiscal information. It may be that absentee owners may not be involved or, because they are not voters, county officials may not feel as compelled to communicate with them through the Web site. Moreover, transparency and demand for open government may be generational with counties with higher percentages of people over age 65 not as pressed to use the Web as a source for constituent information.

Among the four county government variables, one finds mixed results. The FTE variable is insignificant. Contrary to what was hypothesized, having additional administrative staff in a county does not increase the likelihood of a county being more inclined to share fiscal information on the Web site. The size of the county governing board is significant; counties with larger governing boards are 6 percent more likely to be more open and share fiscal information. Larger boards may actually receive more input from constituents than 
smaller boards and, as a result, the larger boards express the need for fiscal information on the county Web site as a communication tool. Moreover, and perhaps just as important, may be a sense by board members that they need easy access to information to conduct official business. In other words, a county with only three elected board members may feel that information can be shared more informally while larger boards may need more formal mechanisms to ensure everyone has the same information.

As expected, a county required to submit an audit was 90 percent more likely to move to higher levels of fiscal transparency. It may well be that the requirement to submit an audit creates an orientation in county officials to be open and responsive. The Appointed Manager variable presents a slightly more complicated picture because it fails to meet the parallel lines assumption and, as noted previously, has three coefficients in Table 2. The first coefficient odds ratio, 1.6681, provides evidence that counties with an appointed manager are 67 percent more likely to have some fiscal information than no information. The first $\gamma$ coefficient provides evidence that having an appointed county manager increases the odds of a county posting at least two fiscal items, rather than none or minimal postings. The third $\gamma$, listed as $\gamma_{-} 2$, is the coefficient for the Appointed Manager variable when the comparison is between counties with the highest level of transparency (three items) compared to all the other counties. The odds ratio for the third $\gamma$ is 2.5467 and is the result of converting the .9348 coefficient to an odds ratio. However, a more useful way of understanding the implications of having an appointed county manager is to add the third coefficient to the first coefficient for this variable $(0.5117+0.9348=$ $1.4465)$ and then transforming the sum into an odds ratio. The result is an odds ratio of 4.2448 and can be interpreted as indicting that a county with an appointed manager is over four times more likely to have the highest level of fiscal transparency than counties without a manager. The results for the Appointed Manager variable provide evidence of the efficacy of the parallel lines test; its explanatory ability is not consistent across all four classifications of counties. The impact that a county manager has on fiscal transparency is not linear with the variable having a much greater explanatory role as transparency increases.

\section{Discussion and Conclusion}

At a time when social media and Web sites are almost passé, a small ( 9 percent) but seemingly significant number of county governments do not even have their own Web sites. Of the 91 percent of the counties with Web sites, many (45 percent) lack the most basic test for fiscal transparency - they do not have a single piece of financial information related to how they spend taxpayers' money, meaning there is no budget or financial statement available. In other words, fiscal transparency is not an instinctive quality demonstrated by county government officials. While this research was able to uncover several explanatory variables, there is still considerable work to be done on why county governments have not fully availed themselves of e-government to create fiscal transparency.

One possible explanatory factor may reside in the relationship between a state and its counties. Traditionally, that relationship has been top-down with states demanding county governments to conduct services and operations in a prescribed manner. Fiscal affairs are no exception with documents ranging from prebudget forms, tax base evaluations, and audit submissions being required of county governments. Interestingly, many states still require county governments to provide notice of fiscal agenda items to the public through newspapers. While speculative, county officials may believe that a requirement for publication of county budget information in a newspaper "lets them off the hook." In other words, the county met the state standards, why do more? The question remains, why more states in this day and age do not require local governments to use Web sites to provide budget information to the public? Texas has done a relatively good job of trying to promote fiscal transparency with the Texas 
Comptroller managing a local government award program for counties that provide financial information on their Web sites. Notwithstanding the Comptrollers efforts, 19 percent of the Texas counties in the sample had no fiscal information and another 44 percent provided only the basic fiscal information. In some sense, carrots (awards) are not sufficient to encourage county governments to be more transparent. One is left to the belief that considerably more work needs to be done to fully understand the relationship between the states and their counties in promoting fiscal transparency.

In the end, while some county Web sites allow citizens to pay taxes or obtain permits online, there are a significant number of counties with little budget and financial information made available to the public. Although we are able to provide insight into the variability of fiscal transparency, there are still many unanswered questions, such as why are smaller counties less likely to have Web sites? Why do counties that should have the capacity to have sophisticated Web sites fail to provide basic information? If a well-developed theory to explain county government fiscal transparency is to be created, much work remains to be done. In conclusion, if fiscal transparency is a sine qua non for good government, then county governments have much to do to improve their status.

\section{Declaration of Conflicting Interests}

The authors declared no potential conflicts of interest with respect to the research, authorship, and/or publication of this article.

\section{Funding}

The authors received no financial support for the research, authorship, and/or publication of this article.

\section{Supplemental Material}

The online data supplements are available at http:// slg.sagepub.com/supplemental.

\section{References}

Benito, Bernardino, and Francisco Bastida. 2009. Budget transparency, fiscal performance, and political turnout: An international approach. Public Administration Review 69:403-17.

Benton, J. Edwin. 2003. The impact of structural reform on county government service provision. Social Science Quarterly 84:858-74.

Benton, J. Edwin. 2005. An assessment of research on American counties. Public Administration Review 65:462-74.

Benton, J. Edwin, James H. Svara, William L. Waugh, Jr., Kenneth A. Klase, Donald C. Menzel, Tanis J. Salant, Gregory Streib, Jacqueline Byers, and Beverely A. Cigler. 2007. Conducting research on counties in the 21st century: A new agenda and database considerations. Public Administration Review 67:968-83.

Carter, Lemuria, and France Belanger. 2005. The utilization of e-government services: Citizen trust, innovation, and acceptance factors. Information Systems Journal 15:5-25.

Dye, Richard F., Nancy W. Hudspeth, and David F. Merriman. 2011. Transparency in state budgets: A search of best practices. Urbana: University of Illinois, Institute of Government \& Public Affairs.

Giles, William A., Gerald T. Gabris, and Dale A. Krane. 1980. Dynamics in rural policy development: The uniqueness of county government. Public Administration Review 40:24-28.

Harder, Carolyn T., and Meagan M. Jordan. 2013. The transparency of county websites: A content analysis. Public Administration Quarterly 37:103-28.

Heald, David. 2003. Fiscal transparency: Concepts, measurement and UK practice. Public Administration 81:723-59.

Ho, Alfred T. 2002. Reinventing local governments and the e-government initiative. Public Administration Review 62:434-44.

Huang, Zhenyu. 2007. A comprehensive analysis of U.S. countries' e-government portals: Development status and functionalities. European Journal of Information Systems 16:149-64.

Ingram, Robert W., and Douglas V. DeJong. 1987. The effect of regulation on local government disclosure practices. Journal of Accounting and Public Policy 6:245-70. 
Joaquin, M. Ernita, and Thomas J. Greitens. 2011. Integrating budget transparency into egovernment websites. In E-Government website development, ed. E. Downey, C. Ekstrom, and A. Jones, 305-19. Hershey, PA: IGI Global.

Kopits, George, and Jon Craig. 1998. Transparency in government operations. Washington, DC: International Monetary Fund.

Long, J. Scott, and Jeremy Freese. 2006. Regression models for categorical dependent variables using stata. 2nd ed. College Station, TX: Stata Press.

Manoharan, Aroon. 2013a. A study of the determinants of county e-government in the United States. The American Review of Public Administration 43:159-78.

Manoharan, Aroon. 2013b. A three dimensional assessment of U.S. county e-government. State and Local Government Review 45:153-62.

Menzel, Donald C., Vincent L. Marando, Roger B. Parks, William L. Waugh, Jr., Beverly A. Cigler, James H. Svara, Mavis Mann Reeves, J. Edwin Benton, Robert D. Thomas, Gregory Streib, and Mark Schneider. 1992. Setting a research agenda for the study of the American county. Public Administration Review 52:173-82.

Mossberger, Karen, Caroline J. Tolbert, and Ramona S. McNeal. 2008. Digital citizenship: The internet, society, and participation. Cambridge, MA: The MIT Press.

National Advisory Council on State and Local Budgeting. 1998. Recommended budget practices: A framework for improved state and local government budgeting. Chicago: Government Finance Officers Association.

Norris, Donald F., and Christopher G. Reddick. 2013. Local e-government in the United States: Transformation or incremental change? Public Administration Review 73:165-75.

Stowers, Genie N. L. 1999. Becoming cyberactive: State and local government on the World Wide
Web. Government Information Quarterly 16: 11-127.

Wilkinson, Victor O., and James J. Cappel. 2005. Impact of economic prosperity and population on e-government involvement. Issues in Information Systems 6:204-9.

Williams, Richard. 2006. Generalized ordered logit/ partial proportional odds models for ordinal dependent variables. The Stata Journal 6:58-82.

\section{Author Biographies}

E. Lee Bernick is a professor in the School of Environmental and Public Affairs at the University of Nevada, Las Vegas. His publications focus on legislative behavior, state and local governments, and survey research.

Jonathan M. Birds is a doctoral candidate in the School of Environmental and Public Affairs at the University of Nevada, Las Vegas. His research interests include public policy, criminal justice, and survey research.

Katheryn Brekken is the director of Communication and Governmental Affairs at the College of Southern Nevada and a doctoral candidate in the School of Environmental and Public Affairs at the University of Nevada, Las Vegas. Her research interests focus on political representation, local governments, and higher education policy.

Al G. Gourrier is a doctoral candidate in the School of Environmental and Public Affairs at the University of Nevada, Las Vegas. His research interests include state and local government, urban studies, public policy, and economic development.

Leander D. Kellogg is a doctoral candidate in the School of Environmental and Public Affairs at the University of Nevada, Las Vegas. His research interests include diversity and social equity in public policy. 